\title{
Publisher Correction: Engineered bidirectional promoters enable rapid multi-gene co-expression optimization
}

Thomas Vogl, Thomas Kickenweiz, Julia Pitzer, Lukas Sturmberger, Astrid Weninger, Bradley W. Biggs (1), Eva-Maria Köhler, Armin Baumschlager (1), Jasmin Elgin Fischer, Patrick Hyden, Marlies Wagner, Martina Baumann, Nicole Borth, Martina Geier, Parayil Kumaran Ajikumar \& Anton Glieder

Correction to: Nature Communications https://doi.org/10.1038/s41467-018-05915-w, published online 4 September 2018.

In the original version of this Article, the link for the Supplementary Information directed to the Peer Review file and the link for the Peer Review file directed to the Supplementary Information. This has now been corrected in the HTML version. The PDF version of the Article was correct at the time of publication.

Published online: 18 February 2021

\begin{abstract}
(c) (i) Open Access This article is licensed under a Creative Commons Attribution 4.0 International License, which permits use, sharing, adaptation, distribution and reproduction in any medium or format, as long as you give appropriate credit to the original author(s) and the source, provide a link to the Creative Commons license, and indicate if changes were made. The images or other third party material in this article are included in the article's Creative Commons license, unless indicated otherwise in a credit line to the material. If material is not included in the article's Creative Commons license and your intended use is not permitted by statutory regulation or exceeds the permitted use, you will need to obtain permission directly from the copyright holder. To view a copy of this license, visit http://creativecommons.org/licenses/by/4.0/.
\end{abstract}

(C) The Author(s) 2021 